\title{
PULMONARY SARCOIDOSIS WITH BONE INVOLVEMENT MIMICKING METASTATIC CANCER
}

\author{
KEMIK TUTULUMU ILE METASTATIK KANSERI TAKLIT EDEN PULMONER SARKOIDOZ \\ OLGUSU
}

\author{
Ece ŞAHINOGLU ${ }^{1}$ iD, Ahmet Hamdi ILGAZLI ${ }^{1}$ (D) \\ ${ }^{1}$ Kocaeli University, Faculty of Medicine, Department of Pulmonary Diseases, Umuttepe, Kocaeli, Turkey
}

ORCID IDs of the authors: E.Ş. 0000-0002-3422-6433; A.H.I. 0000-0001-9017-2014

Cite this article as: Sahinoglu E, llgazli AH. Pulmonary sarcoidosis with bone involvement mimicking metastatic cancer. J Ist Faculty Med 2022;85(1):125-9. doi: 10.26650/IUITFD.853034

\begin{abstract}
Sarcoidosis is a disease of unknown etiology which can affect the lungs and lymph nodes, skin, eyes and other organs and, in rare cases, bones and bone marrow cells. We present a case of a 39-year-old male patient with an iliac bone involvement of sarcoidosis mimicking malignancy. Lymphoma and metastatic cancer proved a challenge to discard in differential diagnosis. He underwent multiple biopsies including tru-cut lung parenchyma and iliac bone biopsies. All of the biopsy specimens were reported as non-necrotising granulomatous inflammation. He underwent corticosteroid treatment. His response to the steroid treatment was insufficient so methotrexate was added to the corticosteroid therapy. Afterwards, clinical and radiological improvement was recorded. We aimed to highlight the utilization of taking new biopsies and histopathological re-evaluations in order to confirm the diagnosis and distinguish a benign disease from a malignant one.
\end{abstract}

Keywords: Sarcoidosis, differential diagnosis, malignancy

\section{ÖZET}

Sarkoidoz, etyolojisi bilinmeyen, özellikle akciğer ile lenf bezlerini, cildi, gözleri ve diğer organları tutabilen; fakat nadiren kemik ve kemik iliğini tutan bir hastalıktır. Otuz dokuz yaşında, iliak kemikte maligniteyi taklit eden lezyonu olan, biyopsi ile sarkoidoz olduğu kanıtlanan bir erkek hastayı sunduk. Lenfoma veya metastatik kanser ayırıcı tanısı yapmak son derece zordu. Hastaya akciğer ve iliak kemikten birçok biyopsi yapıldı. Hepsinin sonucu nonnekrotizan granulomatöz inflamasyon olarak raporlandı. Hastaya kortikosteroid tedavisi başlandı. Steroid tedavisine yeterli yanıt alınamayan hastanın steroid tedavisine metotreksat ilave edildi. Bunun sonrasında klinik ve radyolojik iyileşme kaydedildi. Bu olguda, maligniteyi benign bir hastalıktan ayırt edebilmek ve tanıyı doğrulamak için yeni biyopsilerle ytekrarlanan histopatolojik değerlendirmenin öneminin vurgulanması hedeflendi.

Anahtar Kelimeler: Sarkoidoz, ayırıcı tanı, malignite

\section{INTRODUCTION}

Sarcoidosis is a multisystem, chronic disease characterised by non-necrotising granulomatous inflammation of unknown etiology (1). About $90 \%$ of patients with sarcoidosis have pulmonary involvement (2). As is well known, sarcoidosis may also affect the skin, eyes, kidney, joints and other organ systems, but bone involvement of sarcoidosis is rare, accounting for only $3-13 \%$ of all patients (3). We present a case of a 39-year-old male patient with an iliac bone lesion that mimicked malignancy, yet the confirmed result of the biopsy taken from the lesion proved to be sarcoidosis.

\section{CASE REPORT}

A 39-year-old man was admitted to our outpatient clinic who had been suffering from shortness of breath, malaise and fatigue for one month. His past medical history was unremarkable. He was a nonsmoker and had

Corresponding author/iletişim kurulacak yazar: eceyetiskin@hotmail.com

Submitted/Başvuru: 04.01.2021 • Revision Requested/Revizyon Talebi: 17.02.2021 •

Last Revision Received/Son Revizyon: 27.02.2021 • Accepted/Kabul: 30.03.2021 • Published Online/Online Yayın: 15.11.2021 
been working in a polyvinyl chloride (PVC) pipe factory for 10 years. He had neither fever nor weight loss . Night sweats were absent. A chest computed tomography (CT) was performed after his chest X-ray showed a multifocal reticulonodular pattern in both lung fields and bilateral hilar enlargement (Figure 1). CT revealed multiple, irregular shaped, peribronchovascular nodular lesions, predominantly in the upper lobes in both lung fields (Figure 2). These were initially reported as an infectious disease. Laboratory findings were all within normal limits. Erythrocyte sedimentation rate (ESR) and white blood cell levels were normal. Fiberoptic bronchoscopic evaluation was insignificant. Both lung systems were normal and bronchoalveolar lavage (BAL) fluid was obtained in order to detect infectious disease, predominant cell features and the possibility of malignancy. Tuberculosis smear test, mycobacteria culture, atypical mycobacteria culture and cytology of BAL fluid were within normal limits and there was no sign of infectious disease. Purified protein derivative (PPD) skin test demonstrated no induration and was reported as $0 \mathrm{~mm}$.

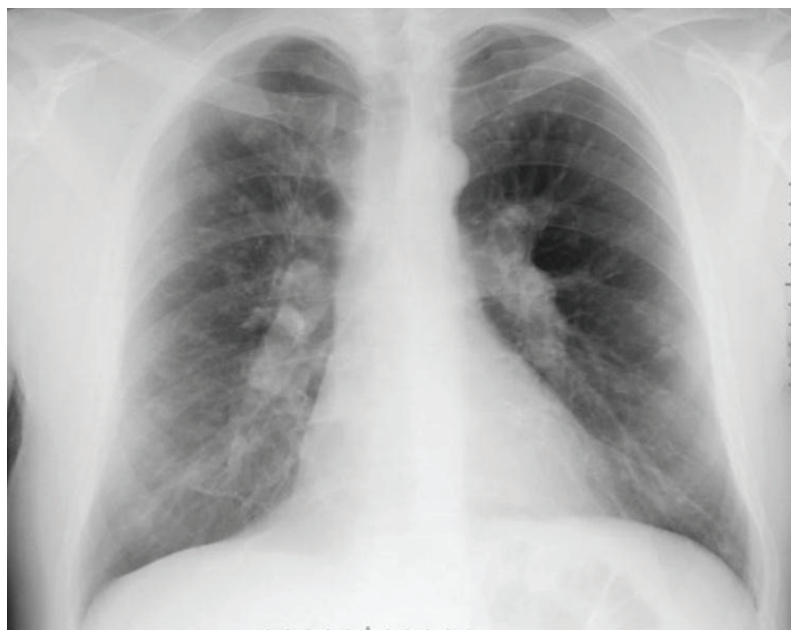

Figure 1: Multifocal reticulonodular pattern in both lung fields and bilateral hilar enlargement

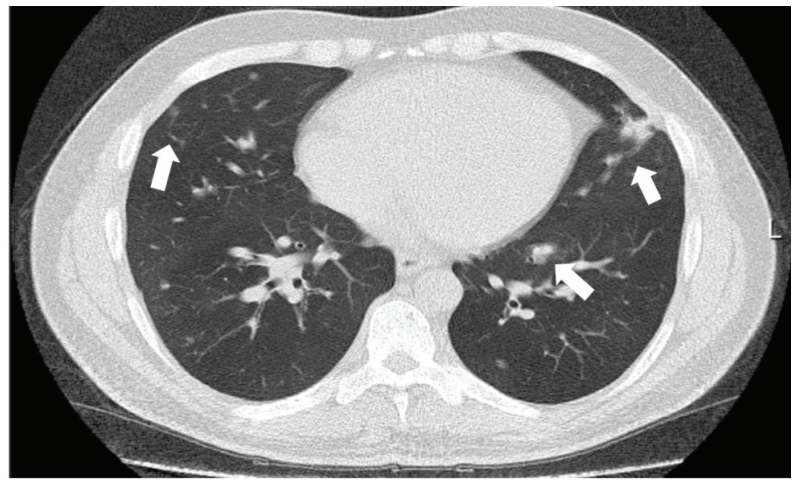

Figure 2: Multiple, irregular shaped, peribronchovascular nodular lesions (organising pneumonia)
Serum calcium, vitamin D levels and angiotensin-converting enzyme (ACE) levels were within normal limits.

Tests performed for syphilis, amoebiasis, brucellosis and also echinococcosis were negative. Thyroid function tests were within normal limits. Tumor markers (Ca 19-9, Ca-125, total and free prostate-specific antigen (PSA), alpha-Fetoprotein (AFP)) and autoantibody profile (antinuclear antibody, antineutrophil cytoplasmic antibody) were examined and all of them were within normal limits, too.

The patient was discussed in our Multidisciplinary Interstitial Lung Disease Council and his illness was classified as organising pneumonia (Figure 2). Methylprednisolone treatment was recommended. Through this therapy the symptoms of the patient improved. At the end of a 1-month- corticosteroid (CS) therapy a chest CT was performed to re-assess the response to therapy and the CT showed the regression of organising pneumonia. Clinical and radiological findings had significantly improved, and a chest $C T$ re-assessment was planned after finishing six months of CS therapy. The patient presented to our clinic for persistent dyspnea after 6 month-corticosteroid treatment. The chest CT showed lymphadenopathies

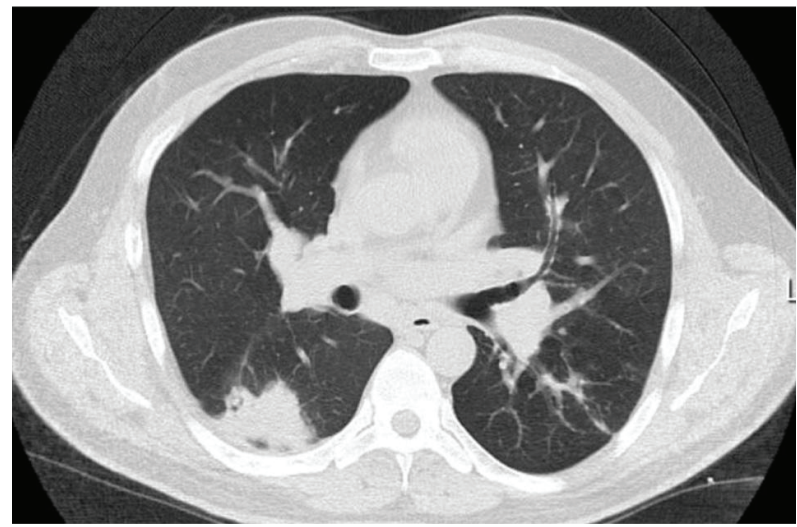

Figure 3a: $4 \mathrm{~cm}$ consolidation in the right lower lobe

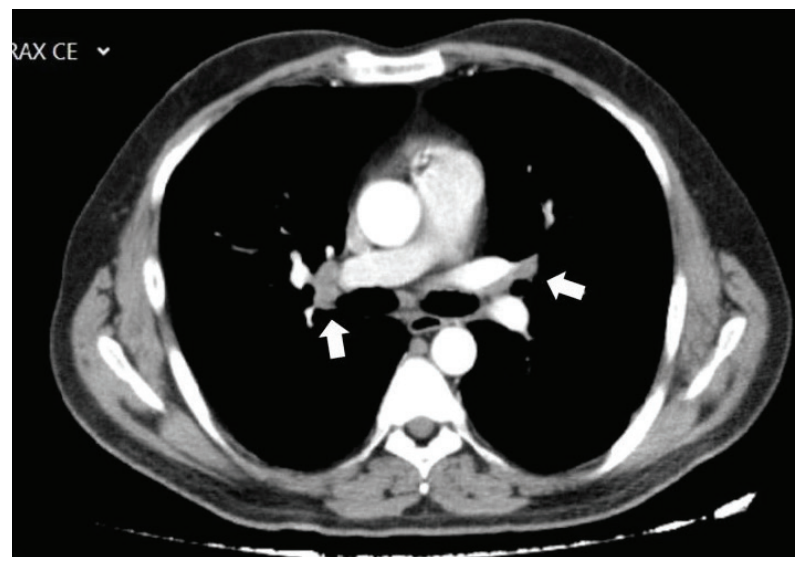

Figure 3b: $2 \mathrm{~cm}$ lymphadenopaties in both hilum 
of $2 \mathrm{~cm}$ in both pulmonary hila and a newly developed peripheral consolidation of $4 \mathrm{~cm}$ in diameter that was located in the superior right lower lobe (Figure 3a, 3b). A transthoracic fine needle aspiration biopsy and tru-cut biopsy were taken from this $4 \mathrm{~cm}$ lesion in the right lung by interventional radiology and histopathological evaluation was reported as non-caseating, non-necrotising granulomatous inflammation. There was no evidence of a malignant neoplasm, according to the report. Bronchoscopic evaluation was performed again for the second time and both a bronchoalveolar lavage (BAL) fluid specimen and a transbronchial biopsy were obtained. The biopsy result was negative for malignancy. BAL fluid examination indicated that the number of CD4 was 3.75 (61\%), the number of CD8 was 1.8 (29.5\%) and the ratio of CD4/CD8 was 2. The percentage of lymphocytes in BAL fluid was $84.9 \%$ (6.323). The Multidisciplinary Interstitial Lung Disease Council decided to continue CS therapy for 1 month due to the increased lymphocyte percentage in the BAL fluid. At the end of 1 month of CS therapy a repeat chest $C T$ revealed the progression of the lesion in the right lower lobe from a size of $4 \mathrm{~cm}$ to $5 \mathrm{~cm}$. Positron emission computed tomography (PET/ $\mathrm{CT}$ ) was ordered to evaluate whether there was any involvement in other parts of the body. PET/CT showed lymphadenopathies of 10 millimeters in diameter in both axillae with a maximum standardized uptake value (mSUV) level of 10, mass lesions of $4 \mathrm{~cm}$ in both lung parenchyma with $16 \mathrm{mSUV}$, and multiple mediastinal and abdominal lymphadenopathies with $15 \mathrm{mSUV}$ and 12 mSUV, respectively. Both the vertebral column and the pelvic bone showed increased metabolic activity with 11.8 mSUV in multifocal areas (Figure 4, 5). An iliac bone biopsy was recommended to the patient so as to show whether the diagnosis is lymphoma or primary lung cancer.

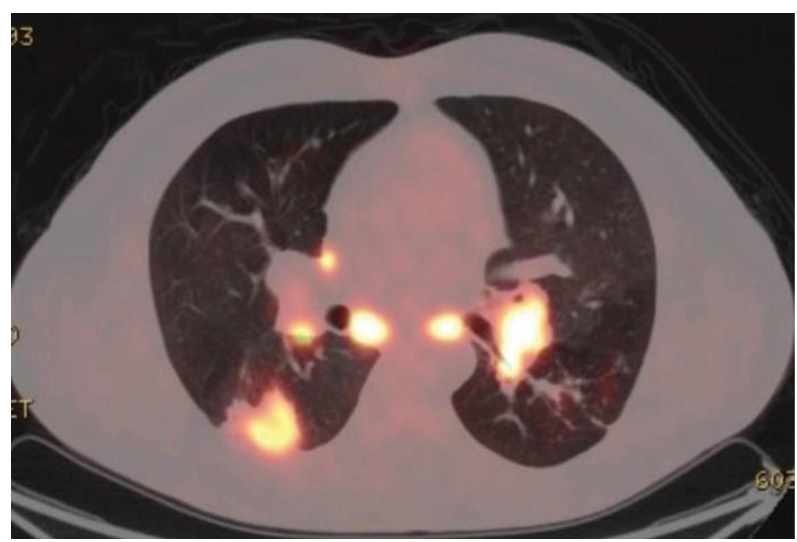

Figure 4: 4-centimeter-mass lesions in both lung parenchyma with $16 \mathrm{mSUV}$, multiple mediastinal lymphadenopaties with 15 mSUV
The CT guided iliac bone biopsy was obtained from the PET positive lesion in the left iliac bone by interventional radiology. The histopathological evaluation was reported as non-caseating, non-necrotising granulomas once again. The patient was diagnosed with steroid-resistant sarcoidosis. Methotrexate, a disease modifying anti-rheumatic drugs (DMARDs) was added to the steroid treatment. Through this combination therapy, the patient's symptoms and radiological findings gradually re-

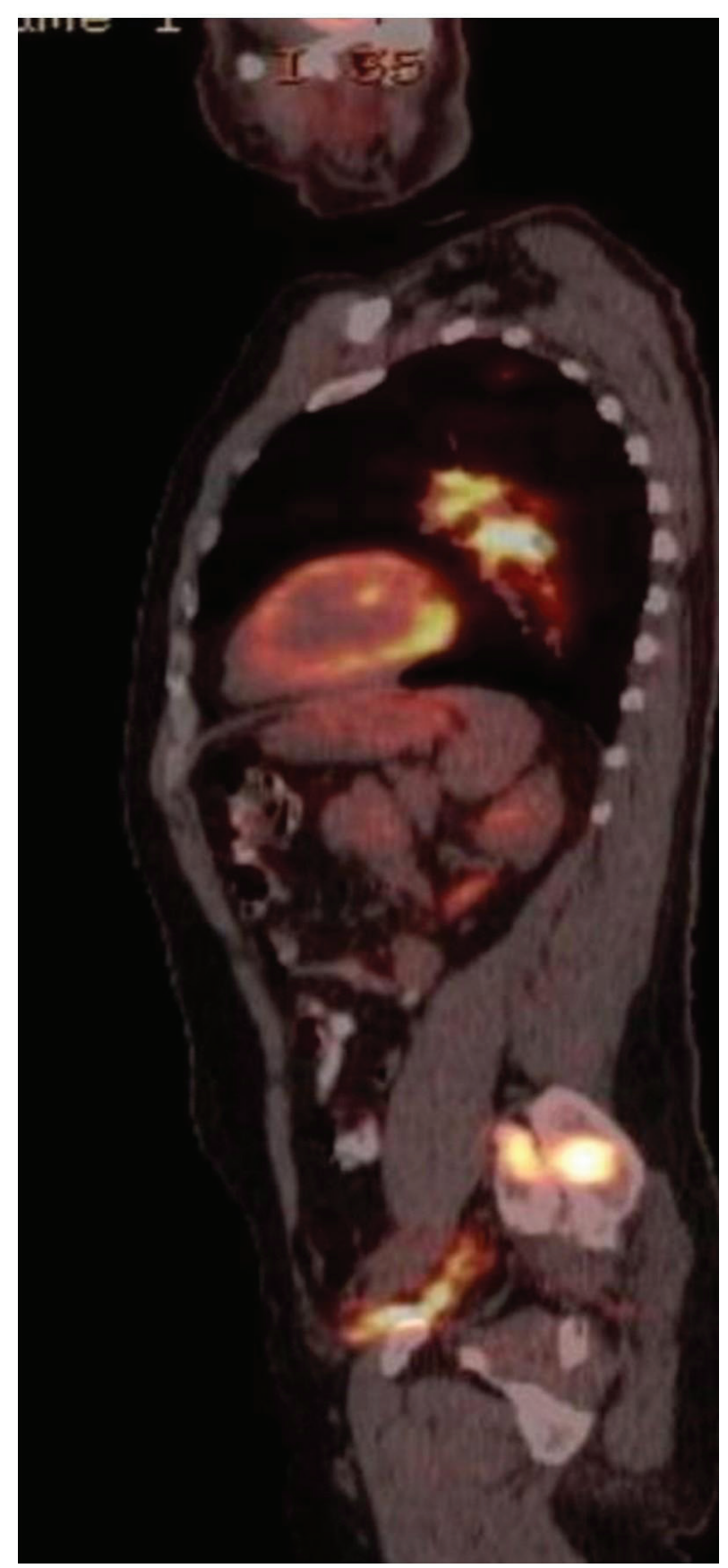

Figure 5: Pelvic bone involvement with 11.8 mSUV 
gressed. Eventually, a chest CT was carried out at the end of six months of combination therapy with methotrexate and tapering dose steroid which revealed that all radiological findings (mass-like lesions, lymphadenopathies and consolidations) improved significantly (Figure 6). In addition to this, the CT did not show any novel lesions. The treatment continued by tapering current doses so as to reduce side effects.

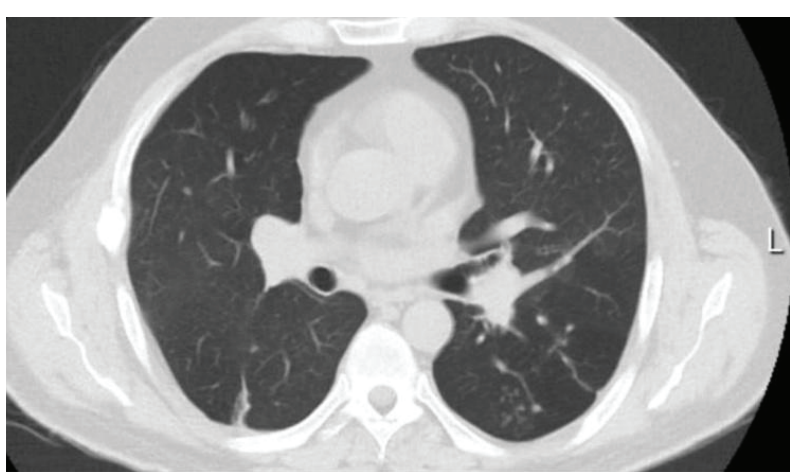

Figure 6: Resolution of mass like lesion and hilar lymphadenopaties

\section{DISCUSSION}

Sarcoidosis is a disease, which may affect multiple organ systems. Ninety percent of patients with sarcoidosis have lung involvement, whereas bone and bone marrow involvement is rare and comprises $3-13 \%$ of all cases. Non-necrotizing granulomatous inflammation is typical in sarcoidosis (1-3). Since both metastatic cancer and lymphoma can have bone and bone marrow involvement, differential diagnosis is crucial to avoid misdiagnosis. In addition to the well-known clinical and radiological manifestations of sarcoidosis, the diagnosis is also made by showing non-caseating epitheloid cell granulomas in biopsy specimens, thus discarding other granulomatous diseases (4).

Our case is special for two reasons. One is that radiological and laboratory findings are not specific for sarcoidosis with a 4-centimeter mass-like lesion, which normally suggests malignancy. A PPD test was also implemented and there was no induration, so it was recorded as $0 \mathrm{~mm}$ which suggests sarcoidosis. On the other hand the ratio of CD4/CD8 more than three in BAL fluid has high specifity for sarcoidosis $(5,6)$, and may be useful. However, this ratio has a low sensitivity for sarcoidosis (7). However, the CD4/CD8 ratio of our patient was two, which is not compatible with sarcoidosis. Serum protein electrophoresis and immunofixation electrophoresis were also measured within normal limits. Serum levels of calcium, vitamin D and ACE were within normal limits. There was no evidence of lymphoproliferative disorders. At this stage the diagnosis was highly challenging, with inadequate evi- dence. Second, at the beginning of CS treatment, clinical and radiological improvement was remarkable, but after a few months it changed and became resistant to steroid therapy. Our first diagnosis, organised pneumonia, was excluded due to the fact that the response to steroid therapy was unsatisfactory. The patient was discussed in our Multidisciplinary Interstitial Lung Disease Council due to the failure of treatment. This made us re-evaluate the patient once again with biopsies and a PET/CT scan in order to rule out metastasis or lymphoma. The PET/ CT scan revealed various high metabolic active lesions whose mSUV level was approximately 15, which suggested a malignant rather than a benign lesion. The pelvic bone indicated $11.8 \mathrm{mSUV}$ level. An iliac bone biopsy was carried out with a high suspicion of malignancy, and a non-necrotising granulomatous inflammation was again reported. After the patient was diagnosed with sarcoidosis with resistance to steroids, we resolved to combine methotrexate with a tapering dose of CS. The response to this combination therapy was extremely good. Both clinical and radiological improvement proved that the diagnosis was sarcoidosis with bone involvement. Bone involvement of sarcoidosis generally has a diminished response to CS treatment, with a poor prognosis, and has a tendency to be multisystemic, as seen in our case (8).

In cases with atypical and obscure elements like this case, clinicians need to take account of differential diagnosis until they make the definitive diagnosis. Additional biopsies and further investigation may be helpful. A multidisciplinary approach may help in managing difficult cases like ours. We recommended our patient to have routine check-ups four times a year so as not to be late in case of malignant transformation.

\section{CONCLUSION}

We presented a young male patient who had involvement in various parts of his body, including bones, and therefore was suspected of having a malignancy at first glance.

However, multiple biopsies revealed that the case was in fact sarcoidosis. It is essential to discard malignancy and other causes of granulomas in cases where radiological and laboratory findings are not consistent with sarcoidosis. Bone involvement of sarcoidosis is an uncommon but significant entity due to its mimicking of metastatic cancer.

Informed Consent: Written consent was obtained from the participants.

Peer Review: Externally peer-reviewed.

Author Contributions: Conception/Design of Study- E.Ş., A.H.I.; Data Acquisition- E.Ş.; Data Analysis/InterpretationA.H.I.; Drafting Manuscript- E.Ş.; Critical Revision of ManuscriptE.Ş., A.H.I.; Approval and Accountability- E.Ş., A.H.I. 
Conflict of Interest: Authors declared no conflict of interest.

Financial Disclosure: Authors declared no financial support.

\section{REFERENCES}

1. Brincker $\mathrm{H}$. The sarcoidosis-lymphoma syndrome. $\mathrm{Br} \mathrm{J}$ Cancer 1986;54(3):467-73. [CrossRef]

2. Heinle R, Chang C. Diagnostic criteria for sarcoidosis. Autoimmunity Reviews 2014;13(4-5):383-7. [CrossRef]

3. James DG, Neville E, Siltzbach LE. A worldwide review of sarcoidosis. Ann N Y Acad Sci 1976;278:321-34. [CrossRef]

4. Statement on sarcoidosis. Joint Statement of the American Thoracic Society (ATS), the European Respiratory Society (ERS) and the World Association of Sarcoidosis and Other Granulomatous Disorders (WASOG) adopted by the ATS Board of Directors and by the ERS Executive Committee, February 1999. Am J Respir Crit Care Med 1999;160(2):73655.
5. Costabel U, Bonella F, Ohshimo S, Guzman J. Diagnostic modalities in sarcoidosis: BAL, EBUS, and PET. Semin Respir Crit Care Med 2010;31(4):404-8. [CrossRef]

6. Danila E, Norkūniene J, Jurgauskiene L, Malickaite R. Diagnostic role of BAL fluid CD4/CD8 ratio in different radiographic and clinical forms of pulmonary sarcoidosis. Clin Respir J 2009;3(4):214-21. [CrossRef]

7. Kantrow SP, Meyer KC, Kidd P, Raghu G. The CD4/CD8 ratio in BAL fluid is highly variable in sarcoidosis. Eur Respir $J$ 1997;10(12):2716-21. [CrossRef]

8. Fernández-Ruiz M, Guerra-Vales JM, Castelbón-Fernández FJ, Llenas-García J, Rodríguez-Peralto JL, López-Lancho R, et al. Sarcoidosis presenting as an osteolytic skull lesion: a case report and review of literature on skull sarcoidosis. Clin Rheumatol 2007;26(10):1745-8. [CrossRef] 